\title{
WestVirginiaUniversity
}

THE RESEARCH REPOSITORY @ WVU

Graduate Theses, Dissertations, and Problem Reports

2013

\section{The Effects of Artificial Photoperiod on Age at Puberty in Fall-born Ewe Lambs}

Matthew Lewis Deacon
West Virginia University

West Virginia University

Follow this and additional works at: https://researchrepository.wvu.edu/etd

\section{Recommended Citation}

Deacon, Matthew Lewis, "The Effects of Artificial Photoperiod on Age at Puberty in Fall-born Ewe Lambs" (2013). Graduate Theses, Dissertations, and Problem Reports. 500.

https://researchrepository.wvu.edu/etd/500

This Thesis is protected by copyright and/or related rights. It has been brought to you by the The Research Repository @ WVU with permission from the rights-holder(s). You are free to use this Thesis in any way that is permitted by the copyright and related rights legislation that applies to your use. For other uses you must obtain permission from the rights-holder(s) directly, unless additional rights are indicated by a Creative Commons license in the record and/ or on the work itself. This Thesis has been accepted for inclusion in WVU Graduate Theses, Dissertations, and Problem Reports collection by an authorized administrator of The Research Repository @ WVU. For more information, please contact researchrepository@mail.wvu.edu. 
The Effects of Artificial Photoperiod on Age at Puberty in Fall-born Ewe Lambs

Matthew Lewis Deacon

Thesis submitted to the Davis College of Agriculture, Natural Resource and Design at West Virginia University in Partial Fulfillment of the Requirements for the Degree of

Master of Science in Reproductive Physiology

Emmett K. Inskeep, Ph.D., Chair Eugene E. Felton, Ph.D. Marlon Knights, Ph.D.

Division of Animal and Nutritional Sciences

Morgantown, West Virginia 2013

Keywords: Sheep, Puberty, Ewe lambs, Fall season

Copyright 2013 Matthew Lewis Deacon 


\section{Abstract \\ The Effects of Artificial Photoperiod on Age at Puberty in Fall-born Ewe Lambs}

\section{Matthew Lewis Deacon}

A study, conducted in two replicates, examined the effects of an artificial photoperiod on puberty in fall-born ewe lambs. Replicate I was initiated in December 2011 with prepubertal Dorset ewe lambs $(\mathrm{n}=44)$. Replicate II was initiated beginning in December 2012 and included prepubertal Dorset, Suffolk x Dorset and Texel x Dorset ewe lambs $(n=52)$. All lambs were weighed at the initiation of each replicate and randomized to one of two treatments, control or treated, based on age, weight, breed and type of birth and rearing. Control ewe lambs were housed in a barn with exposure to natural photoperiod from December 16, 2011 until March 24, 2012 in replicate I and from December 17, 2012 until March 17, 2013 in replicate II. Treated ewe lambs were housed in a section of the same barn, but exposed to natural and supplemental light ( 100 lux at lamb eye level) to produce an artificial photoperiod of 16 hours light and 8 hours dark for 14 weeks, from December 16, 2011 until March 24, 2012 in replicate I and from December 17, 2012 until March 25, 2013 in replicate II. Following completion of light treatment, each treated female received a silastic implant containing $20 \mathrm{mg}$ of melatonin (Melovine), subcutaneously in the ear. Light intensity during the artificial lighting period for the treated group was measured, at random intervals, throughout the experiment and had an average value of 100 lux, at ewe lamb eye level as measured by a Digital Light Meter (LX1010B). Growth of the lambs was monitored, as both weight and age are integral components of puberty. All ewe lambs were weighed at four time points during the study, including onset for each replicate, weaning, light termination and CIDR insertion. Ewe lambs were synchronized for estrus with the use of CIDR-G inserts, administered on May 18 of each year. On May 23 of each year CIDR implants were removed and intact fertile rams introduced. Rams were removed on June 19, 2012 or June 25, 2013 after allowing a breeding period of two opportunities for behavioral estrus. Pregnancy was determined by transrectal ultrasonography 25 days after removal of the rams. Progesterone was assayed, on all animals at four time points, using a radioimmunoassay. Plasma melatonin was assayed, in a subset of both treated and control females in replicate I prior to light termination, using an ELISA method. At light termination; treated females, in replicate I, weighed an average of $52.9 \pm 1.6 \mathrm{~kg}$ compared to $48.1 \pm 1.6 \mathrm{~kg}$ for control females $(\mathrm{P}<0.05)$. Extended light photoperiod increased weight gain in Replicate I, but not in Replicate II. Overall, fall-born Dorset ewe lambs (56 to 57\%) conceived their first spring with no effect of the artificial photoperiod/melatonin treatment. Suffolk- and Texel-sired lambs from Dorset ewes did not have the out-of-season breeding ability seen in the purebred Dorset ewe lambs, even with the artificial photoperiod/melatonin treatment; only 2 of 14 (14\%) of Suffolk-sired ewe lambs conceived. 


\section{Table of Contents}

Abstract ..................................................

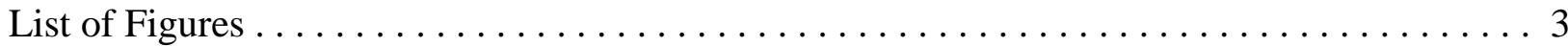

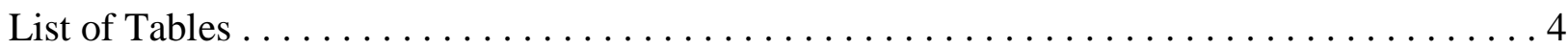

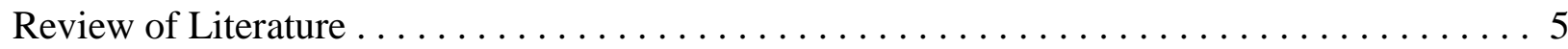

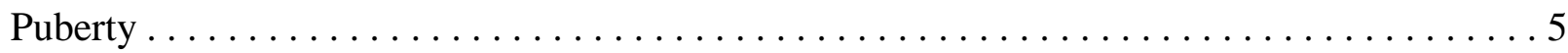

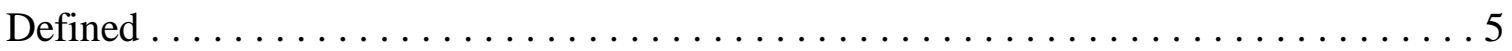

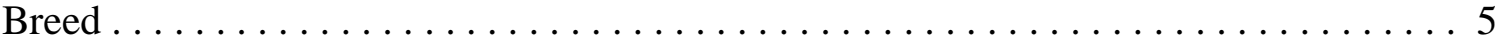

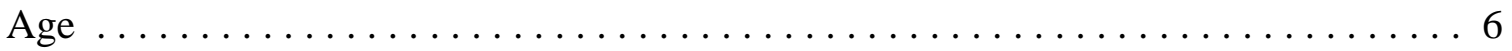

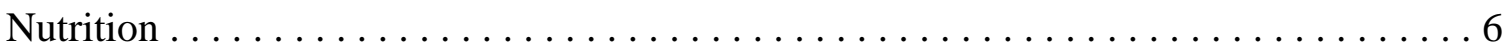

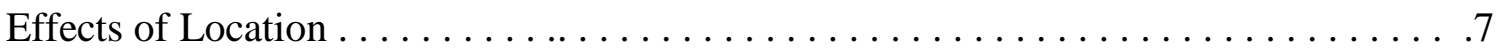

Season of Birth . . . . . . . . . . . . . . . . . . . . . . . . . . .

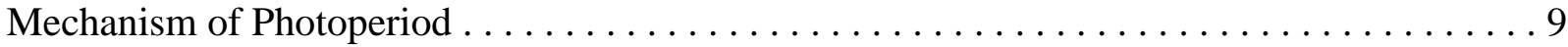

Tools to Hasten Puberty . . . . . . . . . . . . . . . . . . . . . . . . . . . . . 12

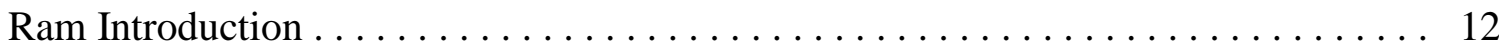

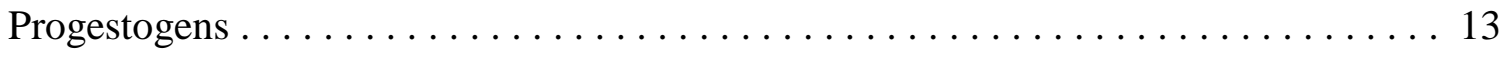

Estrogens .......................................... 14

Gonadotropins ...................................... 15

Melatonin. ............................................

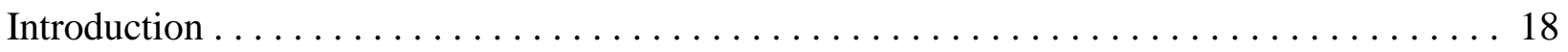

Materials and Methods ...................................... 19

Results .......................................... 23

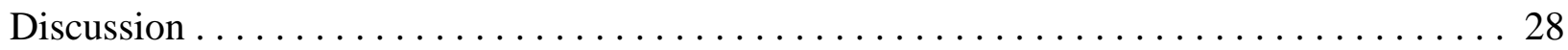

Conclusion ................................................ 30

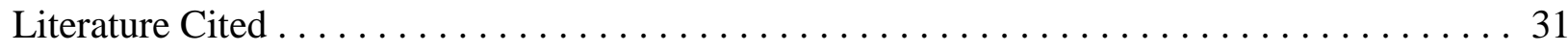

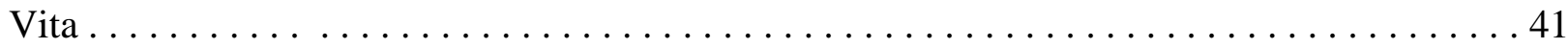

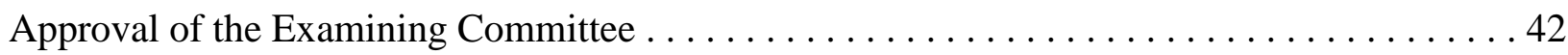




\section{List of Figures}

Figure 1. Cartoon Outlining the Photoperiodic Effect on Neuro-Endocrine Regulation of Seasonal Reproduction in the Sheep . . . . . . . . . . . . . . . . . . . . . . . 11

Figure 2. Control vs. Treated Weights in Replicate I ......................... 24

Figure 3. Serum Concentrations of Progesterone in Ewe Lambs in Replicate I. .......... 25

Figure 4. Control vs. Treated Weights in Replicate II . . . . . . . . . . . . . . . . 27

Figure 5. Serum Concentrations of Progesterone in Replicate II ................. 28 


\section{List of Tables}

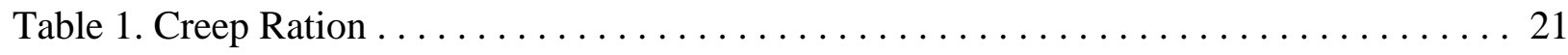

Table 2. Estrous Response in Replicate I . . . . . . . . . . . . . . . . . 24

Table 3. Pregnancy Rate in Replicate I . . . . . . . . . . . . . . . . . . . 25

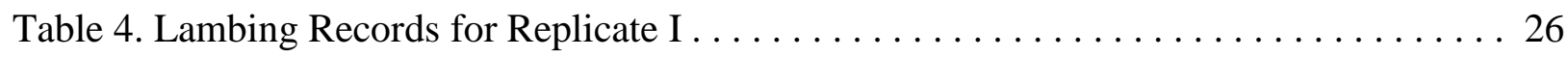

Table 5. Pregnancy Rate in Replicate II . . . . . . . . . . . . . . . . 27

Table 6. Breed Differences in Overall Pregnancy Rate in Replicate II . . . . . . . . . . . . 28 


\section{Review of Literature}

\section{Puberty in the ewe}

Puberty is not a single event or simply defined, but is a complex series of events culminating to produce a fertile estrus, from which a female can carry a pregnancy to term. From a neuroendocrinological standpoint, puberty is defined as the end point of events affecting the development of the hypothalamo-pituitary-gonadal axis. Many different elements contribute to this series of events including nutrition, age, weight, breed of sire and dam, type of birth and location. Each of these elements contributes a small portion to achieve the full development of the pubertal animal. With the current issues of all time high livestock prices, along with increasing feed prices, an understanding of puberty and how it can be manipulated to achieve a greater level of production can be highly advantageous to producers.

Breed. The breed of ewe lambs has proved to play an important role in timing puberty. Various breeds such as the Dorset and Finnsheep that experience a much longer breeding season reach puberty at an earlier age, when compared to Suffolk or Hampshire breeds (Dickerson and Laster, 1975). Ewe lambs of breeds with characteristically short breeding seasons commonly reach puberty at a greater age. Southam et al. (1971) found a significant difference in age at puberty, 189.0 days in Finn X Rambouillet ewe lambs compared to 214.3 days in Rambouillet ewe lambs. Similarly, Bunge et al. (1993) found that Suffolk ewe lambs reached puberty 12.1 days earlier than Targhee ewe lambs.

The breed of sire and breed of dam show an important interaction effect involved with puberty. Hybrid vigor commonly leads to a lessening of the age at onset of puberty. Bunge et al. (1993) found an important interaction of breed of sire and dam on several traits, including 
ovulation rate, breeding to lambing interval, and lamb weaning weight. Selecting sheep based on fertility leads to a decrease in age at puberty. These selection techniques also improve percentage of ewes lambing in the first breeding season. Al-Shorepy et al. (1997) suggested that selecting ewes that lamb in the fall improved out-of-season fertility. Similarly, Vincent et al. (2000) concluded that duration of anestrus is shortest in highly-fertile ewes selected for fall-lambing. These conclusions imply that selecting highly-fertile sheep that breed out-of-season improves the overall fertility in fall-lambing flocks.

Age. Age itself is an important limiting factor with regard to puberty, but age at puberty also is highly variable with season of birth. Berardinelli (1979) summarized the literature showing that ewe lambs born in the fall of the year will not reach puberty until the next breeding season, at approximately one year of age. In contrast, late winter or spring-born lambs reached puberty at approximately 6 to 8 months. Wiggins et al. (1970) found the average age at puberty of fall-born grade Rambouillet ewe lambs was 316 days, but ranged from 197 to 577 days. Dyrmundsson and Lees (1972) found that spring-born Clun Forest ewe lambs reached puberty at an average of $228.3 \pm 2.4$ days. The age at puberty can vary greatly depending on breed, nutrition, and season of birth (Hulet, 1969; Southam, 1971; Dyrmundsson and Lees, 1972; Dyrmundsson, 1973; Foster and Ryan, 1979).

Nutrition. Adequate amounts of growth and adiposity are critical factors in the attainment of puberty in mammalian species. Nutrition provides a huge impact on the attainment of puberty, as it controls various pathways of mediation depending on sufficient or insufficient planes of nutrition. Several studies have shown that increased weight gains, along with greater adiposity, are associated with early onset of puberty. Animals that experience low planes of nutrition, or under nourishment, showed a delayed onset of puberty. Meyer and French (1979) showed that 
within breeds, number of ewe lamb estruses was correlated positively with ewe lamb body weight. Amstalden et al. (2011) concluded that the exact mechanisms and pathways of excess energy balance may not be known, but could be involved in an early escape from estradiol negative feedback, resulting in a high frequency episodic secretion of gonadotropin-releasing hormone $(\mathrm{GnRH})$. Many researchers have shown that extended periods of light have increased the weight gain in species such as sheep and cattle, due to the behavioral aspect of feeding more during more hours of light. Suttie et al. (1991) found that undernourished lambs did not receive internal cues or a photoperiodic stimulus compared to well-nourished ewe lambs. Faster-growing more efficient lambs exhibited first estrus earlier and were more likely to conceive at a younger age and greater body weight than slower-growing lambs (Foster and Ryan, 1979: Dyrmundsson, 1981). Heavier ewe lambs showed greater ovulation rates than lighter animals at the same age (Bizelis et al., 1990).

Season of Birth, Location and Photoperiod. The season of birth is a key component in the occurrence of puberty in various wild and domestic ruminant species. The explanation of these phenomena is not entirely clear, but it has been suggested that changes in photoperiod, abundance of forage nutrients and temperature may be related. Many researchers have studied the difference between attainment of puberty in spring and fall-born ewe lambs. Ebling and Foster (1988) showed that a decreasing daylength was important to initiate puberty in springborn Suffolk ewe lambs. Subsequently, Foster (1981) found that placing fall-born ewe lambs in a photoperiod simulating that which occurs naturally for spring-born lambs hastened puberty. Thus they reached the conclusion that ewe lambs must go through a period of long days, more light than dark, before they are able to reach puberty during short days (Yellon and Foster, 1985). 
Once these conclusions were reached, many researchers began to study what caused such a phenomenon to occur and made attempts to alter the seasonal pattern of breeding. Various studies looked at the use of artificial photoperiods or the use of melatonin to simulate short day lengths. Based on data in Suffolks, Foster (1983) concluded that ewes must be exposed to a set minimum period of long days before they are able to respond to short days by either early pubertal development or early onset of ovarian cycles in adults. Yellon and Foster (1986) found that an artificial long photoperiod of as little as one week duration could allow subsequent short days to initiate ovarian cycles at a normal age in otherwise short-day-reared lambs.

Latitude (distance from the equator) is important due to its correlation with day length. Locations at higher latitudes in the temperate zones have reduced amounts of average daily sunlight, greater alterations of the annual photoperiod rhythm; and may have shorter time foraging, but high quality forages. In contrast, lower latitudes experience a more constant day length and often result in breeds or strains of animals that are no longer affected by seasonal alterations of photoperiod. In temperate latitudes, photoperiod is one of the most important factors controlling seasonal reproductive activity and onset of puberty (Malpaux et al., 1989).

Another aspect relative to location is range conditions versus more intensively managed farming operations. Hulet et al. (1969) demonstrated that only 10 to $12 \%$ of ewe lambs raised under Western range conditions in the U.S.A. reached puberty in their first year. Icelandic ewes maintained in their natural environment, with a highly variable alteration in day length, were entrained to a short breeding season of $\sim 4$ months (Eldon, 1993). 


\section{Mechanism of Photoperiod}

As discussed above, seasonal alterations in photoperiod play a significant role in seasonal breeders, such as sheep. Not only do these seasonal alterations initiate the breeding season in mature ewes, they also serve a functional role in timing the attainment of puberty in sexually immature females. An important issue that needed to be addressed was whether photoperiod affects season of puberty in the sexually immature ewe lamb. Yellon et al. (1985) determined that photoperiod profoundly influenced the timing of puberty in the normally growing spring lamb. The conclusion that ewe lambs must go through a period of long days, more light than dark, before they are able to reach puberty during short days, was reached by Yellon and Foster (1985).

Ebling and Foster (1988) concluded that photoperiodic requirements for puberty in the spring-born lamb differed from those for onset of the breeding season in adult sheep. It had been determined in previous studies that spring-born ewe lambs must experience decreasing day length to attain puberty, but reproductive activity could occur without photoperiodic changes in the adult ewe, due to its photoperiodic history. Foster and Ryan (1979) determined that day length regulated the negative feedback potency of estradiol upon luteinizing hormone (LH) secretion, and thus determined seasonal rhythms of reproductive function in the ewe.

One explanation for the increase of GnRH and LH can be the circadian rhythm of secretion of melatonin by the pineal gland, the duration of which varies with the length of darkness per day. Melatonin has commonly been referred to as the hormone of darkness, and it has been thoroughly studied to determine its effects and regulation in the anestrous ewe. It is known that the plasma concentration of melatonin is significantly influenced by light (reduced) 
vs. darkness (increased). Thus the duration of light per day sets the duration of secretion of melatonin, which is a key facilitator in photoperiodic effects and furthermore in the attainment of puberty. As summarized in Figure 1, the pineal serves the function of secretion of melatonin, and thus regulation of endocrine functions. The photoperiod is perceived by the retina, which signals the superior cervical ganglion, which in turn passes the signal on to the pineal gland to secrete melatonin. The longer period of dark, the greater the secretion of melatonin acting on the hypothalamus, which then secretes gonadotropin releasing hormone $(\mathrm{GnRH})$ in more frequent pulses. Because of the 1:1 relationship of GnRH and LH pulses, the frequency of LH pulses increases accordingly, leading to follicular maturation, greater secretion of estradiol and triggering an LH surge (Karsch et al., 1986).

Rollag et al. (1978) found that it was not the duration of elevated melatonin concentrations that cued reproductive changes, but the time of day at which concentrations were elevated, indicating that elevated concentrations need to overlap the sensitive portion of the circadian oscillation. One of the more important conclusions drawn from research on melatonin was reached by Bittman et al. (1983). They found that day length regulates the negative feedback potency of estradiol upon LH secretion, and thus determines seasonal rhythms of reproductive function in the ewe. With regard to hastening puberty, it seems that the outcome of melatonin treatment in advancing the onset of puberty depends on the time of year (more successful closer to summer solstice) and the age of pre-pubertal lambs (minimum of 20 to 21 weeks) at the beginning of treatment (Stellflug et al., 1994). Pellicer-Rubio et al. (2007) determined that when a long-day treatment was finished before the end of March, melatonin treatment can be replaced by natural photoperiod in anestrous lactating goats. 


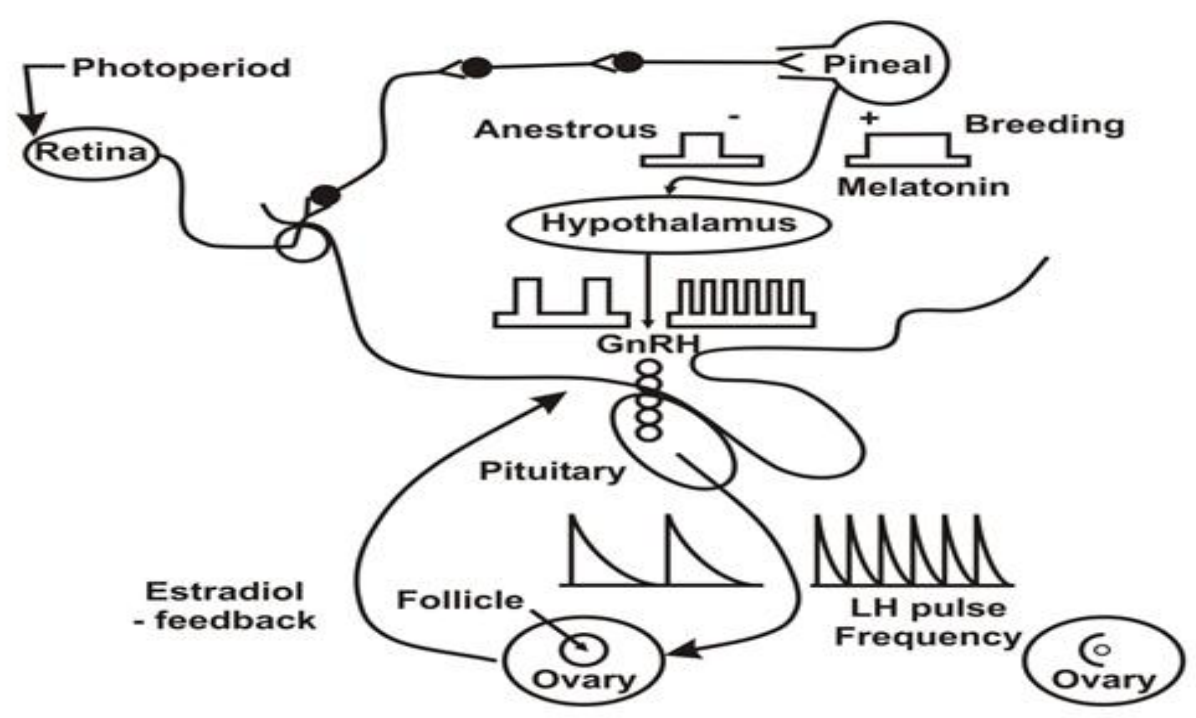

Figure 1. Cartoon Outlining the Photoperiodic Effect on Neuro-endocrine Regulation of Seasonal Reproduction in the Sheep.

Another advantage of treatment of sheep with melatonin can be an increase in fertility and litter size. Both fertility and litter size of treated ewes may be improved in the Rasa Aragonesa, Assaf and Merino breeds; number of lambs produced can be increased by 15 to $30 \%$ depending on farm and time of implantation (Abecia et al., 2007, 2011). In contrast, LopezSebastian et al. (1991) determined that melatonin implantation had added value on earlier cyclic activity or greater ovulation rate and litter size only in ewes that possessed the genetic ability and environmental potential to respond. Specifically, a response was seen when ovulation rate in control ewes was low relative to genetic potential, but not when it was already high. A significant increase of GnRH secretion occurred after 40 days of treatments with melatonin and high pulsatility of GnRH and LH was observed after 74 days of melatonin treatment in anestrous ewes (Viguié et al., 1995). Following the hypothesis that ewe lambs must experience "long day" followed by "short day", Slyter et al. (1997) observed that April-born ewe lambs exposed to 
extended light during the winter had an improved weight gain as well as increased conception rate the following spring.

\section{Tools to Hasten Puberty}

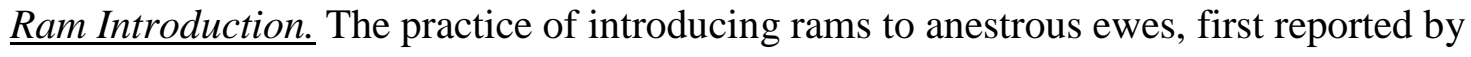
Underwood et al. (1944), and in more detail by Schinkel et al. (1954), has become an invaluable tool in the practice of inducing estrus in anestrous ewes. Knights et al. (2002) showed that introduction of rams to fall-born ewe lambs increased the mean concentration of LH and the LH pulse frequency. The lambs in that study were exposed to long days followed by a declining photoperiod prior to ram introduction, thus reinforcing the concept of a photoperiodic effect on puberty. Al-Mauly et al. (1991) concluded that the earlier introduction and the presence of rams appeared to facilitate an earlier ovulation in ewe lambs compared with isolated controls, probably because of the increase in LH secretion that ensued. In a study conducted by Dyrmundsson and Lees (1972), sudden introduction of rams to ewe lambs partially synchronized estrus during the transition from non-breeding to the breeding season. They also determined that ram introduction resulted in a more concentrated than normal pattern of lambing dates in ewe lamb flocks. In a study conducted by Walkden-Brown et al. (1999), interaction of males with anovulatory but responsive females induced a stimulation of gonadotropin secretion, in both sexes, that culminated in a synchronization of fertile reproductive activity. Lopez-Sebastian et al. (1984) concluded that a single injection of luteinizing hormone releasing hormone (LH-RH) at ram introduction did not improve response compared with ram introduction alone in postpartum anestrous Manchega ewes. Exposure to vasectomized rams for 16 days along with a $20 \mathrm{mg}$ $\mathrm{PGF}_{2 \alpha}$ injection, prior to exposure to intact rams, increased the pregnancy rate early in the breeding season (Smith et al., 1986). 
Progestogens. Dutt and Casida (1948) initially found that injections of progesterone suppressed estrous activity in breeding ewes and withdrawal allowed estrus and ovulation. The use of exogenous progesterone treatments has become a common practice in estrous synchronization in various species, including sheep, goats, and cattle.

Techniques of administration have evolved from the early injections of progesterone to melengestrol acetate [17-hydroxy-6-methyl-16-methylenepregna-4,6-diene-3,20-dione acetate (MGA)] or medroxyprogesterone acetate [6 $\alpha$-17-hydroxy-6-methylpregn-4-ene-3,20-dione (MPA)] as feed additives or flurogestone acetate [9-fluoro-11b,17-dihydroxypregn-4-ene-3,20dione-17-acetate (FGA)] or MPA in intravaginal sponges, to the now popular and common CIDR insert (controlled internal drug release dispenser) that is discussed below. Johnson et al. (1996) demonstrated that low progesterone concentrations after day 6 of the cycle led to ovulation of persistent follicles, a known cause of lowered fertility in cattle (Ahmad et al., 1995). In sheep, the effect on fertility was seen in some studies (Vinoles et al., 1999) and not in others (Evans et al., 2001). During the breeding season, concentrations of progesterone have dramatic effects on follicular growth and fertility in ewes. In an earlier study, Lewis et al. (1974) had indicated that dose of progestogen (20 vs. 40 mg FGA sponges) had a significant effect on timing of the LH surge post sponge removal, on time to onset of estrus and on the relationship of the two characteristics. The LH surge often occurred before onset of estrus on the lower dosage, but at or after the onset of estrus on the higher dosage, when observed at 4-hour intervals.

In recent research there has been a dramatic shift towards the use of exogenous progesterone treatments for out-of-season breeding in the ewe. The controlled internal drug release dispenser type-G (CIDR-G), a solid silicone elastomer progesterone-releasing device is currently marketed world-wide and in the United States since October, 2009. It was developed as 
an alternative to progestogen-containing sponges by Welch et al. (1984) in New Zealand. Wheaton et al. (1992) determined that progesterone treatment, via CIDR inserts, can be utilized along with the ram effect to successfully improve efficiency of lamb production in anestrous ewes. Subsequently, Knights et al. (2001a) showed that the use of either a 5- or a 12- day treatment with a CIDR containing progesterone, followed by ram introduction induced a fertile estrus immediately in a majority of anestrous ewes. In a similar study, Knights et al. (2001b) concluded that a CIDR insert combined with ram introduction at removal was more effective in estrous synchronization of anestrous ewes than ram introduction alone. In conclusion, the use of progestogens has grown and expanded over the past few decades. Wildeus (2000) outlined the current concepts and uses of progestogens in estrous synchronization in small ruminants and provided some implications for the future of the industry.

Estrogens. Estrogens have a strong negative feedback on pulse frequency of secretion of LH during anestrus and suppress puberty in young ewes. Foster and Ryan (1979) conducted a series of studies utilizing ovariectomy and replacement therapy with steroids to examine the mechanism. They concluded that 1) a decrease in response to estradiol inhibition of tonic LH secretion occurs during puberty in the ewe lamb; 2) a stimulus to tonic LH secretion occurs during puberty that is independent of ovarian steroid control and 3) the final processes governing the onset of puberty in the lamb and onset of the breeding season in the adult appear to share a common mechanism, a decrease in the inhibitory feedback response to estradiol on tonic $\mathrm{LH}$ secretion. Burfening (1986) found that ewe lambs treated with steroid hormones, such as estrogen, showed behavioral estrus, but failed to develop a corpus luteum and become pregnant. Results from a study conducted by Southam et al. (1971) indicated a significant increase in the number of corpora lutea present in ovulating ewe lambs given exogenous estrogen when 
compared to those given pregnant mare serum gonadotropin (now known as equine chorionic gonadotropin), or in control ewe lambs. Estrogens can have positive effects on the attainment of puberty. Squires et al. (1972) found that a single injection of estradiol-17 $\beta$ on day 6 after experimental initiation, of four daily injections of FSH-S3 for 4 days or twice daily injections of putrescine for 4 days increased LH concentrations in prepubertal ewe lambs. Similarly, Fitzgerald et al. (1982) discovered that increased serum concentrations of estradiol led to the initiation of an LH surge followed by ovarian luteal activity.

Gonadotropins. The pulse frequency of GnRH acts as a driving force in the attainment of puberty. Ebling et al. (2005) concluded that puberty is a consequence of the reactivation of the GnRH secretory system, leading to a sustained increase in pulsatile GnRH release, which stimulates the release of gonadotropins and in turn gonadal activity. From this conclusion, it can be understood that exogenous GnRH can combat the negative feedback of estrogen, thus inducing ovulation in a pre-pubertal animal. Pirl et al. (1987) indicated that exogenous GnRH could induce ovulation and precocious puberty in ewe lambs, based upon continued cycles. Keisler et al. (1985) observed that during the pubertal process, as mean LH increased there was an associated increase in amplitude but not frequency of LH pulses. Subsequently, Huffman et al. (1987) found LH pulse frequency was similar to that seen in post pubertal lambs one week prior to first progesterone rise. In contrast, they showed that LH pulse amplitude did not increase prior to puberty and in fact declined linearly during the three-week period immediately prior to first ovulation. Reeves et al. (1971) showed that injections of $250 \mu \mathrm{g}$ or $500 \mu \mathrm{g}$ of estradiol benzoate prior to a $3.0 \mu \mathrm{g}$ injection of LH-RH significantly increased mean serum $\mathrm{LH}$ concentrations when compared to controls or a $25 \mu \mathrm{g}$ injection of estradiol benzoate. 
The gonadotropic hormones act as key facilitators in the attainment of puberty in the ewe lamb. Knights et al. (2002) concluded that ram introduction to anestrous fall-born ewe lambs the following summer (July) stimulated follicular development and induced an LH surge. In a similar study, Knights et al. (2001a) determined that an injection of follicle stimulating hormone (FSH) prior to progesterone withdrawal may increase lambing rates and prolificacy, but FSH increased prolificacy only to first service in mature ewes.

Melatonin. The use of melatonin as a feed supplement or an implant has proved to be beneficial in some cases, but lacking in performance in other instances (Eldon, 1993). Eldon (1993) found no effect of melatonin on Icelandic ewes maintained in their natural environment. One of the main disadvantages in studies with melatonin is the confounding interactions of exogenous and endogenous melatonin concentrations in pineal intact animals. Implants of melatonin induced higher plasma concentrations of melatonin for $24 \mathrm{hr}$. every day, without suppressing the endogenous secretions of the pineal hormone during the night (Abecia et al. 2012). Melatonin implants along with ram introduction had no benefit on the number of ewes responding to ram introduction when compared to the use of just ram introduction in some studies (Lopez-Sebastian and Inskeep, 1991) and did have an effect in other studies (Eldon, 1993). In ewe lambs, melatonin was effective only after a period of 4 weeks light exposure along with meeting a threshold weight of approximately $60-70 \%$ of their mature body weight (Kennaway and Gilmore, 1984). Several studies using treatments with progesterone and ram introduction (Al-Mauly, 1991, Knights et al., 2002), including those that used melatonin in feed to simulate short days (T. Holler and E. K. Inskeep, unpublished) have not been successful in hastening puberty in fall-born ewe lambs. 
Stellflug et al. (1989) showed that when 12 weeks of extended light was administered to fall-born Polypay ewe lambs before melatonin implants, reproductive performance was improved more than with melatonin alone or in controls. Lopez-Sebastian et al. (1991) concluded that melatonin implantation was beneficial only in breeds that possessed the genetic ability to respond. The breeding season was extended in mature western range ewes in the spring by about six weeks when $2.5 \mathrm{mg}$ of melatonin was administered daily as an intramuscular injection (Nett and Niswender, 1982). In conclusion, melatonin is a naturally occurring hormone that can reset the biological clock of sheep to reduce seasonality and improve reproductive performance (Stellflug, 1992). 


\section{$\underline{\text { Introduction }}$}

Typically ewe lambs born in the fall of the year will not reach puberty until the next breeding season, at approximately one year of age (Berardinelli, 1979). Late winter-born or spring-born ewe lambs usually reach puberty at a much younger age, at approximately 6 to 8 months of age. To maximize lifetime productivity in sheep in out-of-season lambing programs, fall-born ewe lambs need to conceive in spring, but most attempts in common breeds have had low success rates. Researchers have examined the various factors that contribute to the onset of puberty. The most significant factor to effect differences in age at puberty in sheep is photoperiod. Foster (1981) found that placing fall-born Suffolk ewe lambs in a photoperiodic environment simulating that which occurs naturally for spring-born lambs hastened puberty. Yellon and Foster (1985) reached the conclusion that Suffolk ewe lambs must go through a period of long days, more light than dark, before they are able to reach puberty during short days. They reported that a continuous exposure to long or short days delayed ovarian cyclicity beyond one year of age. They also determined that blocks of long days followed by short days, at 3 to13 weeks of age, resulted in a few cyclic animals, but when the block of long days occurred at 12 to 22 weeks of age normal luteal cycles began at a "normal" age equivalent to spring-born lambs (34 weeks). Finally, the duration of longer light exposure was examined and found to be effective in a 5-week block, but also effective for a 1-week block. Subsequently, Ebling and Foster (1988) showed that a decreasing daylength was important to initiate puberty in springborn ewe lambs.

In anestrous adult ewes, treatment with progesterone for as few as 5 days, in combination with ram introduction at progesterone withdrawal, is effective in inducing fertile estrous cycles (Knights et al., $2001 \mathrm{a}, \mathrm{b}$ ). Several studies using treatments with progesterone and ram 
introduction, including those that used melatonin feeding to simulate short days (T. Holler and E. K. Inskeep, unpublished) have not been adequate to induce puberty during spring months in fallborn ewe lambs, although Knights et al. (2002) induced an estrous response in 82\% of fall-born ewe lambs in July. In contrast, Slyter et al. (1997) found that exposure to long days (16 hours in Trials I and II, 18 hours in Trial III) during December to February increased the proportion of April-born crossbred ewe lambs that lambed after exposed to teaser rams beginning on April 1 and intact rams on April 15 (for 35 days) the following year. Percent of ewes lambing was $83.8 \%$ of treated ewes compared to only $57.3 \%$ of control ewes, so puberty was apparently advanced. This information reinforces the idea that light sequence is the basis for the great differences in age at puberty in ewe lambs. Lambs sired by Hampshire rams from Finn-Dorset-Targhee ewes did not respond as well as Finn-Dorset-Targhee lambs. These results fit with the shorter breeding season reported in the Hampshire breed by Hafez (1952).

The objectives of the present experiment were to determine: 1) if an artificial photoperiod, of 16 hours light and 8 hours dark, in the fall/winter of the year (similar to that of the summer photoperiod) followed by implantation of melatonin will hasten puberty or response to progesterone and ram introduction in fall-born purebred Dorset, Dorset x Suffolk and Texel x Dorset ewe lambs; and 2) if an artificial photoperiod will increase weight gain in prepubertal fall-born ewe lambs.

\section{Materials and Methods}

A study was conducted to examine the effects of an artificial long photoperiod on hastening puberty in fall-born ewe lambs, at a cooperating producer's farm in Aurora, West Virginia, (latitude 39.58, longitude 79.34, elevation 2933 ft.) beginning in December, 2011 and replicated beginning in December 2012. 
Forty-four prepubertal fall-born Dorset ewe lambs (Replicate I) or fifty-two prepubertal fall-born Dorset, Dorset x Texel and Dorset x Suffolk ewe lambs (Replicate II) were randomized within breed type, age, type of birth and rearing to one of two groups, control or treated. In Replicate I, control ewe lambs $(\mathrm{n}=22)$ were housed in a barn with exposure to natural photoperiod as it occurred from December 16, 2011 until March 24, 2012. The treated ewe lambs $(n=22)$ were housed in a section of the same barn, but exposed to an artificial photoperiod consisting of 16 hours light and 8 hours dark for a period of 14 weeks, from December 16, 2011 until March 24, 2012. In Replicate II, control ewe lambs $(n=26)$ were housed in the same barn with exposure to natural photoperiod as it occurred from December 17, 2012 until March 25, 2013. The treated ewe lambs $(n=26)$ were housed in a section of the same barn, but exposed to an artificial photoperiod consisting of 16 hours light and 8 hours dark for a period of 14 weeks, from December 17, 2012 until March 25, 2013. The barn was divided by black plastic sheeting preventing control lambs from being exposed to the supplemental light provided to the treated lambs. There was one change in the barn between replicates. A light panel (row of windows) was added on the east side of the barn, which contained the control group. Thus the control group received the morning sunlight more intensely during the second than the first replicate. Following completion of light treatment, each treated female received a silastic implant containing $20 \mathrm{mg}$ of melatonin (Melovine), subcutaneously in the ear. Light intensity during the artificial lighting period for the treated group was measured, at random intervals, throughout the experiment and had an average value of $\sim 100$ lux, at ewe lamb eye level as measured by a Digital Light Meter (LX1010B).

In the early stages of the treatment period, ewe lambs were housed with their dams and sibling wethers. All lambs had access to a supplemental creep ration (Table 1), beginning prior to 
initiation of the study. All ewe lambs were weaned from the ewes on January 28, 2012 (Replicate I) or on February 16, 2013 (Replicate II). Wether lambs were marketed prior to the time at which ewe lambs were weaned. Growth was monitored, as both weight and age are integral components of puberty. All ewe lambs were weighed at four time points during light treatment, including beginning of each replicate, weaning, light completion and at CIDR insertion. All lambs were provided free access to an ad libitum creep ration during the treatment phase (Table 1). After light completion, ewe lambs were comingled and received a daily ration at a maintenance level of $0.5-1 \mathrm{lb}$. along with free access to pastures of native grasses.

Table 1: Creep Ration

\begin{tabular}{|l|l|l|l|}
\hline Ingredient & \% Ration & & \\
\hline Corn & $64.92 \%$ & \% TDN & 85.1 \\
\hline Soy Hulls & $16.00 \%$ & \% CP & 16.5 \\
\hline Soybean Meal & $14.82 \%$ & \% & 0.55 \\
\hline SS Sheep Mineral & $2.50 \%$ & $\% \mathrm{P}$ & 0.36 \\
\hline Limestone & $1.24 \%$ & & \\
\hline Salt & $0.45 \%$ & & \\
\hline $\begin{array}{l}\text { Sodium } \\
\text { Bicarbonate }\end{array}$ & $0.045 \%$ & & \\
\hline
\end{tabular}

Jugular venous blood samples were collected at four time points: 1) at light completion; 2) 1 week prior to CIDR (Pfizer Animal Health, New York, NY) insertion; 3) at CIDR insertion; and 4) 7 days post ram introduction (Replicate I only). Each sample was centrifuged at $4{ }^{\circ} \mathrm{C}$ for $20 \mathrm{~min}$ at 1,000 $\mathrm{xg}$ and the serum was drawn off, placed in a glass vial and allowed to freeze at $15^{\circ} \mathrm{C}$. Progesterone was assayed, on all animals at four different time points, using the RIA method described by Sheffel et al. (1982).

Plasma melatonin was assayed, in a subset of both treated and control females in replicate I prior to light completion, using the ELISA method. Samples were collected at $7 \mathrm{pm}$ to allow for a difference in treated and control females in light versus dark environments. Due to a 
miscommunication with the cooperating producer, control lambs were exposed to light for a short period of time, then were re-exposed to dark conditions. Due to this accident, melatonin measurements were possibly taken too soon to detect a difference. The control females had an average value of 0.859 compared to an average of 0.744 in the treated females.

Ewe lambs were synchronized for estrus with the use of CIDR-G inserts, administered on May 18 of each year. During CIDR insertion one ewe lamb (\#1869, Replicate I) was found to possess a small vagina, so that insertion was incomplete. She was later found to possess a malformed reproductive tract and was therefore removed from the experiment. On May 23 of each year all ewe lambs were weighed and at that time, CIDR implants were removed and intact fertile rams were introduced. Rams had passed a breeding soundness exam prior to introduction in both replicates. Prior to ram exposure, on May 7, 2012 or April 18 or 24, 2013, all ewe lambs were shorn and treated for internal parasites. All 40 ewe lambs and 4 rams were pastured together, thus the ewe to ram ratio was 10:1 in Replicate I. In Replicate II all 50 ewe lambs and 4 rams were pastured together, thus the ewe to ram ratio was 12.5:1. Rams were equipped with marking harnesses to monitor estrous activity. Estrous marks were recorded 7 days post ram introduction in Replicate I. Rams were removed on June 19, 2012 or June 25, 2013 after allowing a breeding period of two opportunities for behavioral estrus (Knights et al., 2001). Pregnancy was determined by transrectal ultrasonography (Aloka 500 console, $7.5 \mathrm{MHz}$ linear probe) 25 days after removal of the rams.

In Replicate I, two ewe lambs from the treated group and one from the control group died from unknown causes while the study was being conducted, but enterotoxemia was suspected. One female that was originally assigned to the treated group moved herself to the control group shortly after the study was initiated. A portion of the ewe lambs in Replicate I was marketed as 
pregnant to lamb in the fall through the Performance-Tested Ram Lamb and Replacement Ewe Sale, conducted at the Reymann Memorial Farm in Wardensville on July 21, 2012. Ewe lambs that were diagnosed as pregnant were due to lamb by mid to late November, 2012. Ewe lambs that were diagnosed as not pregnant also were marketed through the Performance-Tested Ram and Replacement Ewe Sale. One ewe lamb (control group) that was unfit to breed due to poor growth and structural unsoundness was removed from the study and marketed at the owner's discretion.

In Replicate II, a total of 3 ewe lambs died, one from drowning and two from probable enterotoxaemia. The majority of the ewe lambs was retained within the owner's personal flock and the remainder was marketed on an individual basis.

Statistical analysis. Lamb weights and gain per day at each stage, as well as concentrations of melatonin in replicate I and concentration of progesterone at each time point were compared between treatments by Students t-test. Concentrations of progesterone at CIDR insertion were classified as above or below the threshold of $0.3 \mathrm{ng} / \mathrm{mL}$ reported by Keisler et al. (1983) as an indicator of first ovulation during puberty, and compared at each stage by Chi-square with Fisher's exact test (using SAS Version 9.3). Likewise, proportional data for estrus and pregnancy were examined by Chi-square.

\section{$\underline{\text { Results }}$}

$\underline{\text { Replicate I: }}$ Average weights at onset of the study were $17.8 \pm 1.0 \mathrm{~kg}$ for treated females compared to $17.7 \pm 1.1 \mathrm{~kg}$ for control and average age was $53 \pm 1.5$ days in each group. Weaning weights for treated females were $35.4 \pm 1.2 \mathrm{~kg}$ compared to $33.6 \pm 1.9 \mathrm{~kg}$ for control females. At light termination; treated females weighed an average of $52.9 \pm 1.6 \mathrm{~kg}$ compared to $48.1 \pm 1.6 \mathrm{~kg}$ for control females $(\mathrm{P}<0.05)$. Light-treated ewes weighed an average of $50.5 \pm 3.0 \mathrm{~kg}$ compared 
to $47.9 \pm 3.2 \mathrm{~kg}$ for controls at the time of CIDR implantation (Figure 2). Estrus was recorded by equipping the intact rams with marking harnesses, and data were classified based upon the

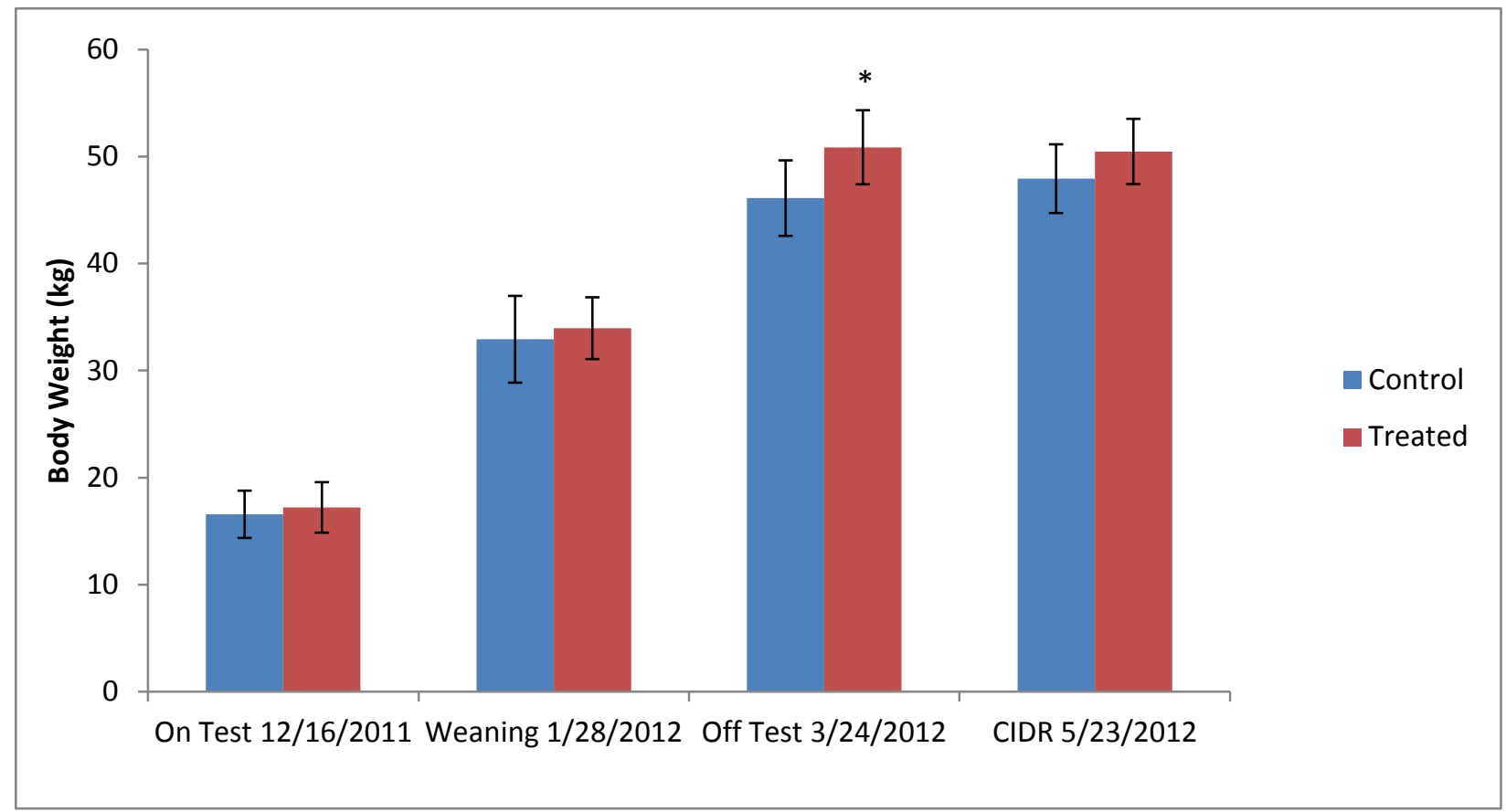

Figure 2. Control vs. Treated Weights in Replicate I. An asterisk indicates a difference (P 0.05) between controls and treated.

degree of marking on the rumps of the ewes. Treated females had 14/18 (78\%) heavily marked, 1/18 (5\%) mildly marked and 3/18 (17\%) light markings. Control females displayed similar responses ( $\mathrm{P}=0.23$; Table 2); 12/21 (57\%) had heavy markings, 1/21 (5\%) had mild markings, and 4/21 (19\%) had light marks, but 4/21 (19\%) had no marks at all. Perhaps surprisingly, 11/21 $(52 \%)$ of control ewe lambs were pregnant to first service compared to $6 / 18(33 \%)$ in the treated

\begin{tabular}{llllll}
\hline \multicolumn{6}{l}{ Table 2. Estrous Response in Replicate I } \\
\hline
\end{tabular}


group $(\mathrm{P}=0.33$; Table 3$)$. After a second service period, overall pregnancy rates were $14 / 21$ (67\%) control and 8/18 (44\%) treated females $(\mathrm{P}=0.21$; Table 3).

\begin{tabular}{rlll}
\hline \multicolumn{4}{l}{ Table 3. Pregnancy Rate in Replicate I } \\
\hline N & 1st Service & $2^{\text {nd }}$ Service & Overall \\
Control (\%) $\mathbf{2 1}$ & $11(52 \%)$ & $3(30 \%)$ & $14(67 \%)$ \\
Treated (\%)18 & $6(32 \%)$ & $2(17 \%)$ & $8(44 \%)$ \\
Overall (\%) 39 & $17(43 \%)$ & $5(23 \%)$ & $22(56 \%)$ \\
\hline
\end{tabular}

Concentrations of progesterone from jugular venous blood obtained from control and treated groups at four time points are shown in Figure 3. Progesterone concentrations were greater on 5/11/2012 (One-week prior to CIDR insertion) in treated females $(\mathrm{P}<0.05)$ and tended to be greater at CIDR removal $(\mathrm{P}=0.06)$. Mean concentrations of progesterone at the end

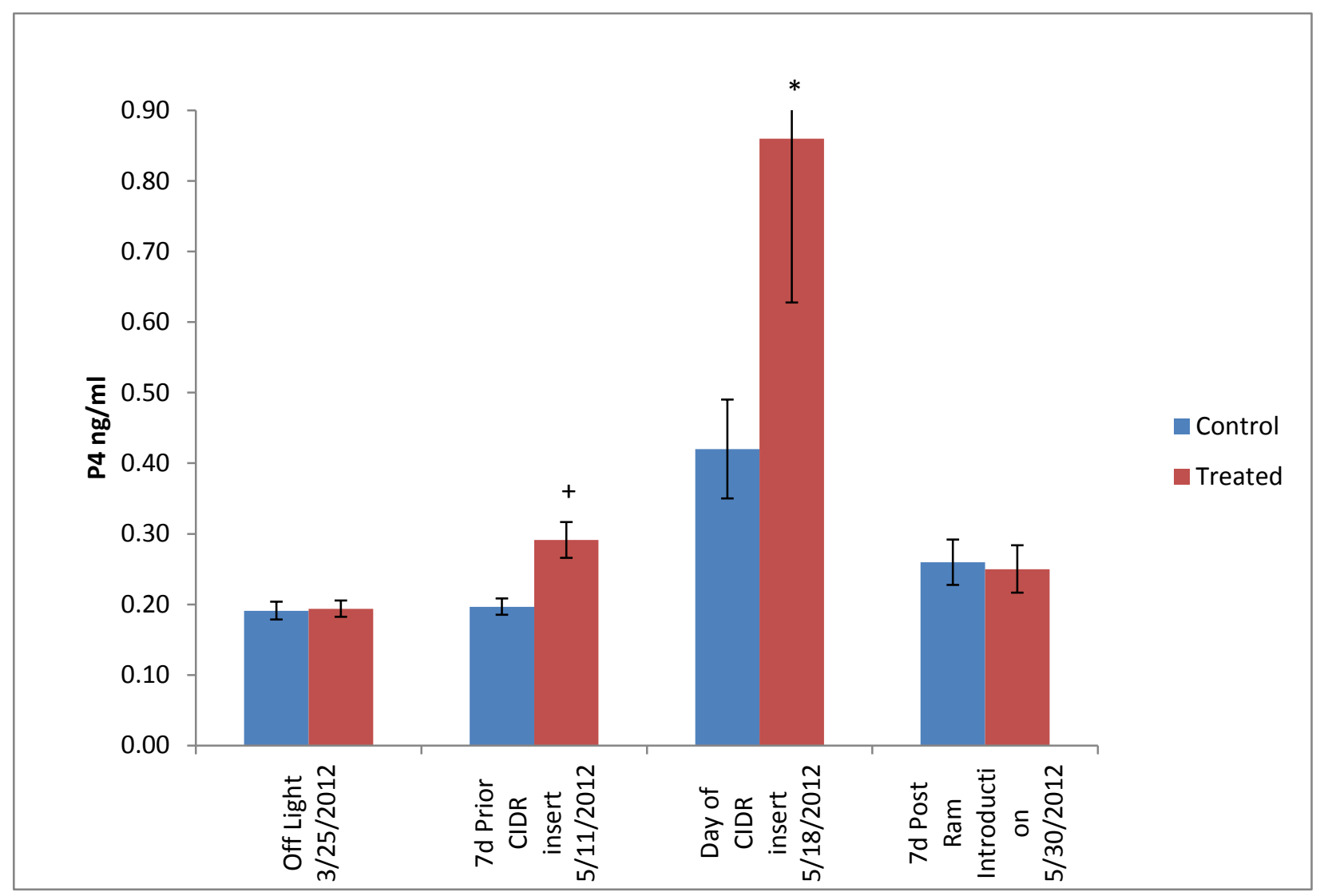

Figure 3. Serum Concentrations of Progesterone in Ewe Lambs in Replicate I. * P $<0.05 ;+\mathrm{P}=$ 0.06 . 
of light treatment and 7 days after ram introduction were not different between groups $(\mathrm{P}>0.05)$. Proportions of ewe lambs with progesterone greater than $0.3 \mathrm{ng} / \mathrm{mL}$ at CIDR insertion did not differ between treated $(11 / 21)$ and control (14/18) animals. $(\mathrm{P}=0.18)$ Lambing data were recorded for all pregnant ewe lambs except one (1835). Treated females produced 7 lambs, consisting of 4 males and 3 females, with an average birth weight of 6 pounds (based on 5 lambs). One set of twins was born in the treated group while the remainder was born as singles. Two of the treated females that were confirmed pregnant failed to lamb due to late fetal death. The control females produced 18 lambs, 9 males and 9 females, with an average weight of 7 pounds (based on 14 lambs). Control females produce five sets of twins and eight single lambs (Table 4).

Table 4. Lambing Records for Replicate I.

\begin{tabular}{|lr|c|c|c|}
\hline Group & $\mathbf{N}$ & Single & Twin & Fail to Lamb \\
\hline Treated & 8 & 5 & 1 & 2 \\
\hline Control & 13 & 8 & 5 & 0 \\
\hline
\end{tabular}

$\underline{\text { Replicate II: Average weights at beginning of light treatment were } 15.6 \pm 1.8 \mathrm{~kg} \text { for }}$ treated females compared to $15.0 \pm 1.6 \mathrm{~kg}$ for control and average age was $43 \pm 3.5$ days in each group. Weaning weights for treated females were $32.4 \pm 2.0 \mathrm{~kg}$ compared to $34.6 \pm 2.1 \mathrm{~kg}$ for control females. At light termination; treated females averaged $46.0 \pm 2.1 \mathrm{~kg}$ compared to $48.6 \pm$ $2.2 \mathrm{~kg}$ for control females. Light-treated ewes had an average weight of $53.9 \pm 9.2 \mathrm{~kg}$ compared to $51.6 \pm 8.3 \mathrm{~kg}$ for controls at the time of CIDR implantation ( $>0.05$ at all stages; Figure 4). Estrous marks were not recorded in Replicate II due to scheduling conflicts.

Concentrations of progesterone from jugular venous blood obtained from control and treated groups at three time points are shown in Figure 5. Progesterone concentrations were greater at day of CIDR insert in control females $(\mathrm{P}=0.06)$. Mean concentrations of progesterone 
at the end of light treatment and day of CIDR removal were not different between groups (P > 0.05). The proportion of ewe lambs with progesterone greater than $0.3 \mathrm{ng} / \mathrm{mL}$ at CIDR insertion was greater in treated $(20 / 26)$ than in control $(11 / 24)$ lambs $(\mathrm{P}<0.03)$.

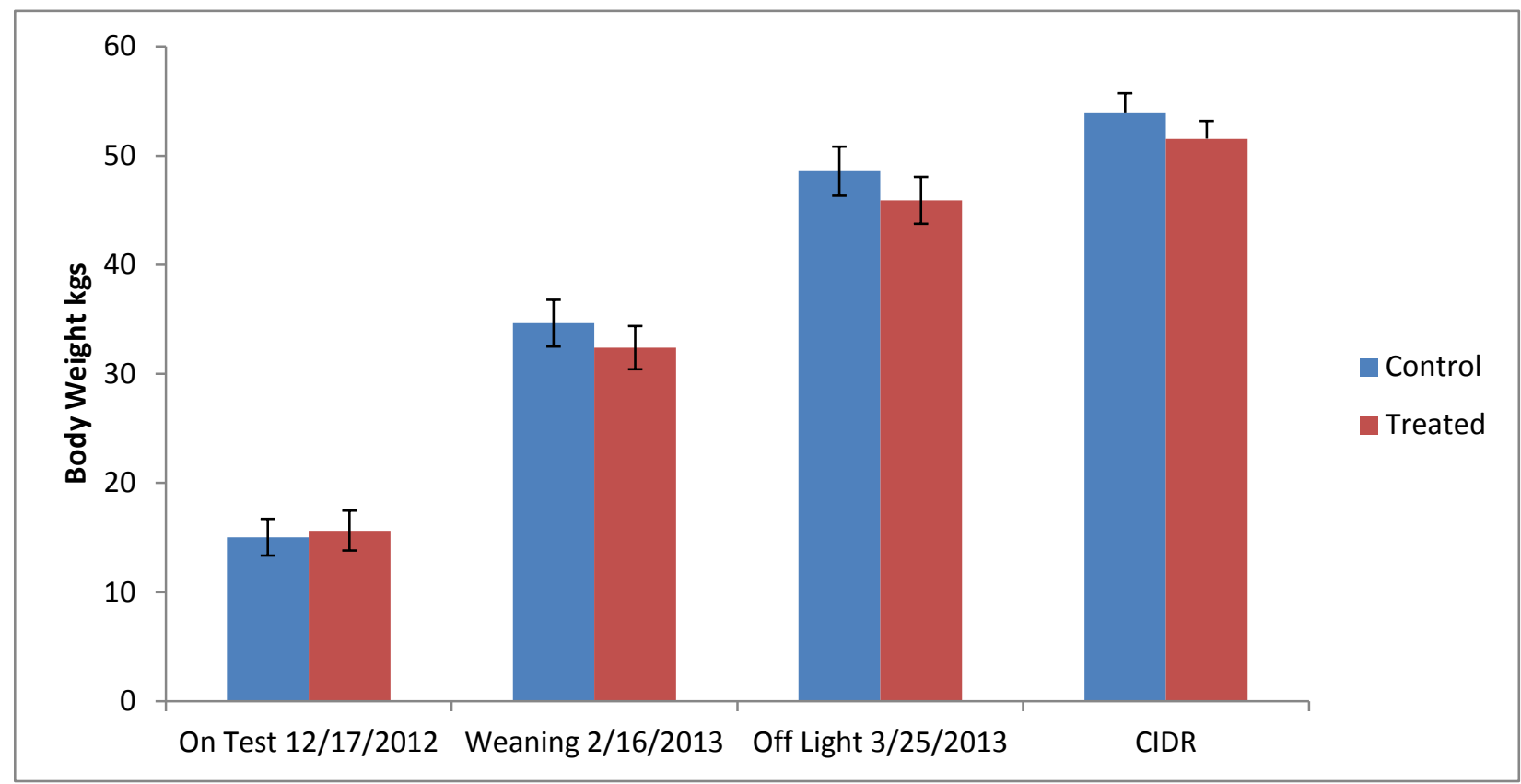

Figure 4. Control vs. Treated Weights Replicate II. There were no differences due to treatment. Unlike in replicate I, only 4/23 (17\%) control ewe lambs and 5/26 (19\%) in the treated group were pregnant to first service. After a second service period, overall pregnancy rates were $7 / 23(30 \%)$ control and 8/26 (31\%) treated females $((\mathrm{P}>0.05$; Table 5).

\begin{tabular}{llll}
\hline \multicolumn{4}{l}{ Table 5. Pregnancy Rate in Replicate II } \\
\hline $\mathbf{N}$ & 1 st Service & $2^{\text {nd }}$ Service & Overall \\
Control (\%) $\mathbf{2 3}$ & $4(17 \%)$ & $3(13 \%)$ & $7(30 \%)$ \\
Treated (\%)26 & $5(19 \%)$ & $3(12 \%)$ & $8(31 \%)$ \\
Overall (\%) $\mathbf{4 9}$ & $9(18 \%)$ & $6(12 \%)$ & $15(31 \%)$ \\
\hline
\end{tabular}


Overall pregnancy rates were lower than in replicate I, but were largely influenced by breed $(\mathrm{P}<0.001$; Table 6$)$. Thus the results for Dorsets $(57 \%)$ were similar overall to replicate I (56\%), and did not differ with treatment.

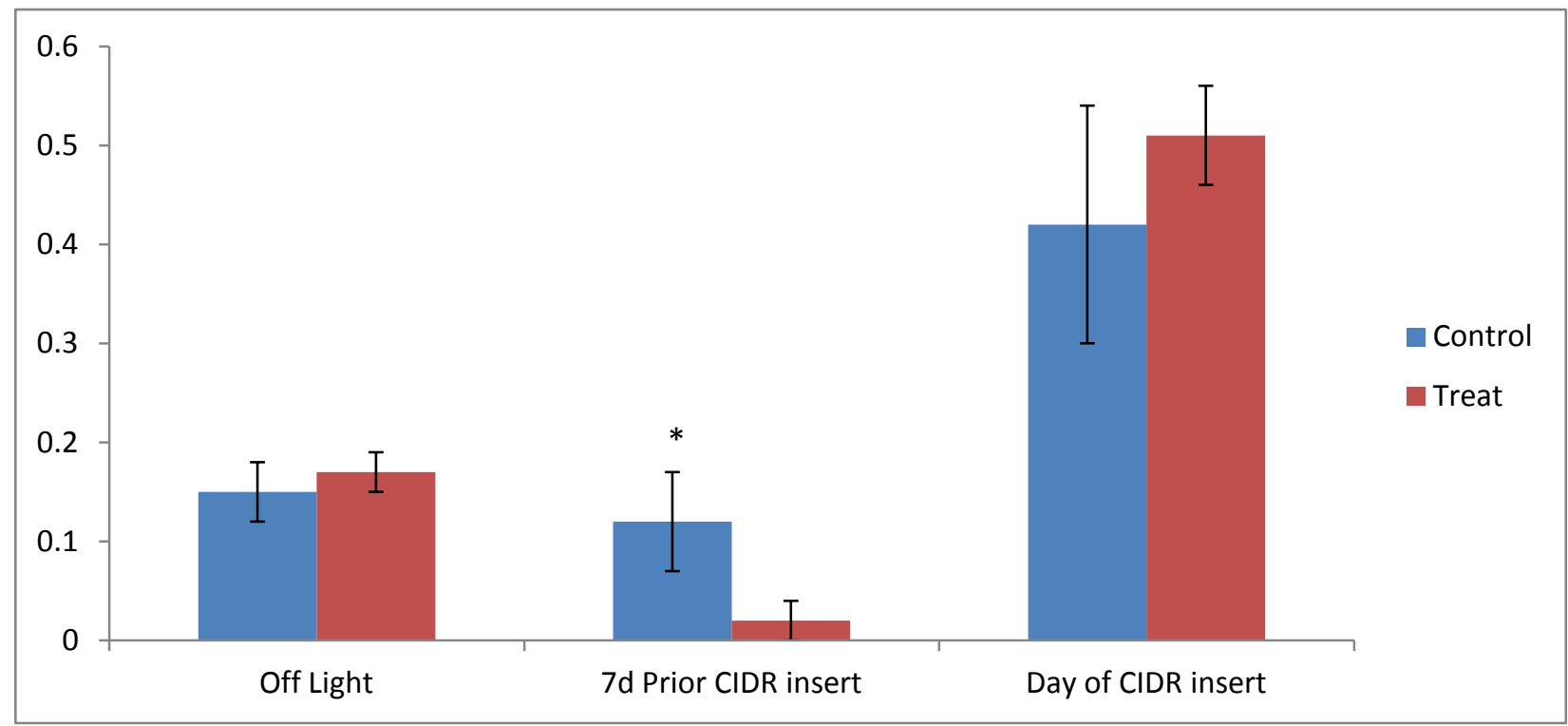

Figure 5. Serum Concentrations of Progesterone in Replicate II. * $\mathrm{P}=0.06$.

\begin{tabular}{rrr}
\hline \multicolumn{4}{c}{ Table 6. Breed Differences in Overall Pregnancy } & Rate in Replicate II \\
\hline N & Pregnant & Open \\
Dorset Sired (\%) $\mathbf{2 3}$ & $13(57 \%)$ & $10(43 \%)$ \\
Suffolk Sired (\%) $\mathbf{1 4}$ & $2(14 \%)$ & $12(86 \%)$ \\
Texel Sired (\%) $\mathbf{1 2}$ & $0(0 \%)$ & $12(100 \%)$ \\
\hline
\end{tabular}

\section{$\underline{\text { Discussion }}$}

The results showed that some fall-born Dorset ewe lambs will breed out-of-season without the aid of artificial photoperiods. This result contrasts with reports by others in various breeds of sheep. Based on data in Suffolk ewe lambs born in fall, Foster (1983) concluded that ewes must be exposed to a set minimum period of long days before they are able to respond to short days by either early pubertal development or early onset of ovarian cycles in adults. 
Similarly, Slyter et al. (1997) found that exposure to long days (16 hours in Trials I and II, 18 hours in Trial III) during December to February increased the proportion of April-born Finn $\mathrm{x}$ Dorset x Targhee crossbred ewe lambs raised under range conditions that lambed after exposed to teaser rams beginning on April 1 and intact rams on April 15 (for 35 days) the following year.

In Replicate II, a breed difference was observed in relation to puberty in fall-born ewe lambs. Despite the use of estrous synchronization techniques that induced cyclicity in a portion of Dorset ewe lambs, ewe lambs sired by Suffolk or Texel rams from Dorset ewes did not become pregnant in response to light treatment and melatonin implants, CIDR insert and ram introduction. In several studies, treatments with progesterone and ram introduction, including those that used melatonin feeding to simulate short days (T. Holler and E. K. Inskeep, unpublished) have not been adequate to induce puberty during spring months in crossbred fallborn ewe lambs, although Knights et al. (2002) induced an estrous response in 82\% of fall-born ewe lambs in July. The Suffolk and Texel breeds are known for shorter breeding season breeds that impact their likelihood of expressing ability to breed out-of-season. Slyter et al. (1997) determined that lambs sired by Hampshire rams from Finn-Dorset-Targhee ewes did not respond as well as Finn-Dorset-Targhee lambs. These results fit with the shorter breeding season reported in the Hampshire breed by Hafez (1952).

The timing of the study could be responsible for the present results, due to the age of the lambs being younger than 12-weeks of age when the light period was initiated. In previous work, Yellon and Foster (1985) determined that blocks of long days followed by short days, at 3 to13 weeks of age, resulted in a few cyclic animals, but when the block of long days occurred at 12 to 22 weeks of age, normal luteal cycles began at a "normal" age, equivalent to spring-born lambs (34 weeks). Finally, the duration of longer light exposure was examined and found to be 
effective in a 5-week block, but also effective for a 1-week block. These results may explain why some of the Dorset ewe lambs in Replicates I and II became cyclic and a portion remained noncyclic.

However, a small portion of the Suffolk-sired ewe lambs in Replicate II did respond to treatments and became cyclic. This could be explained due to the influence of the Dorset dam and their known ability for out-of-season breeding. Various breeds such as the Dorset and Finnsheep that experience a much longer breeding season reach puberty at an earlier age, when compared to Suffolk or Hampshire breeds (Dickerson and Laster, 1975).

The decrease in weight from light termination to CIDR insertion in Replicate I was likely due to the change from confinement to pasture along with a reduction in feed from ad libitum to a maintenance ration. Extended light increased weight gain in fall-born Dorset ewe lambs in Replicate I. Weight gain was not increased due to light treatment compared to controls in Replicate II, which is likely due to the increased morning light seen by the control group.

In addition to the value of lambing at an earlier age there may be monetary advantages for marketing spring-bred, fall-born ewe lambs. Ewes from the trial were sold at the West Virginia Ram Lamb Performance Test Sale in July 2012. Prices averaged \$341 for ewe lambs pregnant to first service, $\$ 350$ for those pregnant to second service, and $\$ 315$ for non-pregnant ewe lambs to be bred in August or September. The higher sale prices minus added expenses resulted in an estimated net gain of $\$ 56.65$ over sale for slaughter at an earlier age.

\section{Conclusions}

The use of extended light photoperiod increased weight gain in Replicate I, but not Replicate II. A portion of fall-born Dorset ewe lambs will breed out-of-season their first spring 
without the aid of artificial photoperiod. Suffolk and Texel sired lambs from Dorset ewes did not show to have the out-of-season breeding ability seen in the purebred Dorset ewe lambs. However, two Suffolk sired ewe lambs did conceive.

\section{Literature Cited:}

Abecia, J.A., Forcada, F., Gonzalez-Bulnes, A. 2012. Hormonal control of reproduction in small ruminants. Anim. Reprod. Sci. 130: 173-179.

Abecia, J.A., Forcada, F., Gonzalez-Bulnes, A. 2011. Pharmaceutical control of reproduction in sheep and goats. Vet. Clin. N. Am. Food Anim. Pract. 27, 67-79.

Abecia, J.A., Forcada, F., Valares, J.A., Palacín, I., Martín, S., Martino, A., Gómez, M.I., Palacios, C. 2005. Does melatonin treatment during lactation influence milk production in Lacaune and Assaf ewes? Span. J. Agric. Res. 3, 1-6.

Abecia, J.A., Valares, J.A., Forcada, F., Palacín, I., Martín, S., Martino, A. 2007. The effect of melatonin on the reproductive performance of three sheep breeds of Spain. Small Rumin. Res. $69,10-16$.

Ainsworth, L. and Shrestha, J.N.B. 1987. The reproductive performance of ewe lambs in a controlled environment. Anim. Prod. 44-233-240.

Al-Mauly, N.Z.N, Bryant, M.J. and Cunningham, F.J. 1991. Effect of the introduction of rams on the pulsatile release of luteinizing hormone and the onset of reproductive activity in ewe lambs. Anim. Prod. 53:209-214.

Al-Shorepy, S.A. and Notter, D.R. 1997. Response to selection for fertility in a fall-lambing sheep flock. J. Anim. Sci. 75:2033-2040.

Barrell, G.K., Thurn, L.A., Brown, M.E., Viguie, C. and Karsch, F.J. 2000. Importance of photoperiodic Signal quality to entrainment of the circannual reproductive rhythm of the ewe. Biol. Reprod. 63:769-774.

Berardinelli, J.G. 1979. Factors involved in the attainment of puberty in female domestic ruminants. Ph. D. Dissertation, West Virginia University, Morgantown, 139 pages.

Berardinelli, J.G., Dailey, R.A., Butcher, R.L. and Inskeep, E.K. 1980. Source of Circulating Progesterone in Prepubertal Ewes. Biol. Reprod. 22:233-236. 
Bittman, E.L., Karsch, F.J. and Hopkins, J.W. 1983. Role of the pineal gland in ovine photoperiodism: Regulation of seasonal breeding and negative feedback effects of estradiol upon luteinizing hormone secretion*. Endocrinology. 113:329-336.

Bittman, E.L, Dempsey, R.J. and Karsch, F.J. 1983. Pineal melatonin secretion drives the reproduction response to daylength in the Ewe*. Endocrinology. 113:2276-2283.

Bittman, E.L., Karsch, F.J. 1984. Nightly duration of Pineal melatonin secretion determines the reproductive response to inhibitory day length in the ewe. Biol. Reprod. 30:585-593.

Bizelis, J.A., Deligeorgis, S.G., Rogdakis, E. 1990. Puberty attainment and fertility characteristics in ewe lambs of Chios and Karagouniki breed raised on two planes of nutrition. Anim. Reprod. Sci. 23, 197-212.

Bunge, R., Thomas, D.L. and Nash, T.G. 1993. Performance of hair breeds and prolific wool breeds of sheep in Southern Illinois: Lamb production of $F_{1}$ ewe lambs. J. Anim. Sci. 71:20122017.

Burfening, P.J. and Berardinelli, J. G. 1986. Effect of feed treatment and exogenous estrogen and progesterone on puberty and lambing rates in ewe lambs. J. Anim. Sci. 63:1717-1721.

Cushwa, W.T., Bradford, G.E., Stabenfeldt, G.H., Berger, Y.M., Dally, M.R. 1992. Ram influence on ovarian and sexual activity in anestrous ewes: Effects of isolation of ewes from rams before joining and date of ram introduction. J. Anim. Sci. 70:1195-1200.

Dickerson, G.E. and Laster, D.B. 1975. Breed, Heterosis and environmental influences on growth and puberty in ewe lambs. J. Anim. Sci. 41:1-9.

Dutt, R.H. and Casida, L.E. 1948. Alteration of the estrual cycle in sheep by use of progesterone and its effect upon subsequent ovulation and fertility. Endocrinology. 43:208-217.

Dyrmundsson, O.R., Lees, J.L. 1972. Attainment of puberty and reproductive performance in Clun Forest ewe lambs. J. Agric. Sci. Camb. 78, 39-45.

Dyrmundsson, O.R., Lees, J.L. 1972. Effects of rams on the onset of breeding activity in Clun Forest ewe lambs. J. Agri. Sci. Camb. 79:269-271.

Dyrmundsson, O.R. 1973. Puberty and early reproductive performance in sheep. 1. Ewe lambs. Anim. Breed. Abstr. 41, 273.

Dyrmundsson, O.R. 1981. Natural factors affecting puberty and reproductive performance in ewe lambs: a review. Livest. Prod. Sci. 8, 55-65.

Ebling, F.J.P., Foster, D.L. 1988. Photoperiod requirements for puberty differ from those for the onset of the adult breeding season in female sheep. J. Reprod. Fertil. 84:283-293.

Ebling, F.J.P. 2005. The neuroendocrine timing of puberty. Reproduction 129:675-683. 
Eldon, J. 1993. Effect of exogenous melatonin and exposure to a ram on the time of onset and duration of the breeding season in Icelandic sheep. J. Reprod. Fert. 99:1-6.

English, J., Poulton, A.L., Arendt, J. and Symons, A.M. 1986. A comparison of the efficiency of melatonin treatments in advancing oestrous in ewes. J. Reprod. Fert. 77:321-327.

Evans, A.C.O., Flynn, J.D., Quinn, K.M., Quinn, P., Madgwick, S., T.F. Crosby, T.F., Boland, M.P. and Beard, A.P. 2001. Ovulation of aged follicles does not affect embryo quality or fertility after a 14-day progestagen estrus synchronization protocol in ewes. Theriogenology 56:923-936.

Fitzgerald, J. and Butler. W.R. 1982. Seasonal effects and hormonal patterns related to puberty in ewe lambs. Biol. Reprod. 27:853-863.

Foote, W.C., Pope, A.L., Chapman, A.B. and Casida, L.E. 1959. Reproduction in the yearling ewe as affected by breed and sequence of feeding levels. I. Effects on ovulation rate and embryo survival. J. Anim. Sci. 18:453-462.

Foster D. L. 1981. Mechanism for delay of first ovulation in lambs born in the wrong season (Fall). Biol. Reprod. 25:85-92.

Foster, D.L., Ryan, K.D. 1979. Endocrine mechanisms governing transition into adulthood: a marked decrease in inhibitory feedback action of estradiol on tonic secretion of luteinizing hormone in the lamb during puberty. Endocrinology 105, 896-904.

Foster, D.L., Ryan, K.D. 1981. Endocrine mechanisms governing transition into adulthood in female sheep. J. Reprod. Fertil. Suppl. 30, 75-90.

Foster, D. L., Ryan, K.D. and Papkoff, H. 1984. Hourly administration of luteinizing hormone induces ovulation in prepubertal female sheep. Endocrinology 115: 1179-1185.

Foster, D.L., Olster, D.H. 1985. Effect of restricted nutrition on puberty in the lamb: patterns of tonic luteinizing hormone ( $\mathrm{LH})$ secretion and competency of the LH surge system. Endocrinology 116, 375-381.

Foster, D.L., Karsch, F.J., Olster, D.H., Ryan, K.D. and Yellon, S.M. 1986. Determinants of puberty in a seasonal breeder. Recent Prog. Horm. Res. 42:331-384.

Foster, D. L., Ebling, F. J. P. and Claypool, L. E. 1988. Timing of puberty by photoperiod. Reprod. Nutr. Develop. 28: 349-364.

Gaskins, C.T., Snowder, G.D., Westman, M.K. and Evans, M. 2005. Influence of body weight, age, and weight gain on fertility and prolificacy in four breeds of ewe lambs. J. Anim. Sci. 83:1680-1689.

Hall, D.G., Fogarty, N.M. and Gilmour, A.R. 1986. Seasonality of ovulation and estrus, and the ram effect in Poll Dorset ewes. Theriogenology 25:455-461. 
Hafez, E.S.E. 1952. Studies on the breeding season and reproduction in the ewe. J. Agr. Sci. 42:189.

Huffman, L.J., Inskeep, E.K. and Goodman, R.L. 1987. Changes in episodic Luteinizing Hormone secretion leading to puberty in the lamb. Biol. Reprod. 37:755-761.

Hulet, C.V., Wiggins, E.L. and Ercanbrack, S.K. 1969. Estrus in range ewe lambs and its relationship to lifetime reproductive performance. J. Anim. Sci. 28:246.

Hulet, C.V. and Stormshak, F. 1972. Some factors affecting response of anestrous ewes to hormone treatment. J. Anim. Sci. 34:1011-1019.

Inskeep, E.K., Barr, A.L. and Cunningham, C.J. 1967. Repeatability of prolificacy in sheep. J. Anim. Sci. 26:458-461.

Inskeep, E.K., Stevens, L. P. and Rudy, C. R. 1979. Fertility in ewes receiving low doses of estradiol during synchronized estrus. J. Anim. Sci. 48: 52-53.

Jackson, G.L., Gibson, M. and Kuehl, D. 1988. Photoperiodic disruption of photorefractoriness in the ewe. Biol. Reprod. 38:127-134.

Jackson, G.L., Jansen, H. and Kao, C. 1990. Continuous exposure of Suffolk ewes to an equatorial photoperiod disrupts expression of the annual breeding season. Biol. Reprod. 42:6373.

Johnson, S.K., Dailey, R.A., Inskeep, E.K. and Lewis, P.E. 1996.Effect of peripheral concentrations of progesterone on follicular growth and fertility in ewes. Domes. Anim. Endocrinol. 13:69-79.

Jordan, K.M., Inskeep, E.K. and Knights, M. 2009. Use of gonadotropin releasing hormone to improve reproductive response of ewes introduced to rams during seasonal anestrus. Anim. Reprod. Sci. 116:254-264.

Jordan, R.M., Rust, J.W. and Chiou, P.W.S. 1970. Effect of energy levels provided ewe lambs post-weaning on their development and subsequent production. J. Anim. Sci. 31:950-955.

Karsch, F.J., Bittman, E.L., Robinson, J.E., Yellon, S.M., Wayne, N.L., Olster, D.H. and Kaynard, A.H. 1986. Melatonin and photorefractoriness: Loss of response to the melatonin signal leads to seasonal reproductive transitions in the ewe. Biol. Reprod. 34:265-274

Keisler, D.H., Inskeep, E.K. and Dailey, R.A. 1983. First luteal tissue in ewe lambs: Influence on subsequent ovarian activity and response to hysterectomy. J. Anim. Sci. 57:150-156. 
Keisler, D.H., Inskeep, E.K. and Dailey, R.A. 1985. Roles of pattern of secretion of luteinizing hormone and the ovary in attainment of puberty in ewe lambs. Domestic Animal Endocrinology. $2: 123-132$.

Kennaway, D J., Gilmore, T.A., Seamark, R.F. 1982.Effect of melatonin feeding on serum prolactin and gonadotropin levels and the onset of seasonal estrus cyclicity in Sheep. Endocrinology 110: 1766-1772.

Kennaway, D J., Gilmore, T.A. 1984. Effects of melatonin implants in ewe lambs. J. Reprod. Fertil. 70:39-45.

Knights, M., Baptiste, Q.S., Lewis, P.E. 2002. Ability of ram introduction to induce LH secretion, estrus and ovulation in fall-born ewe lambs during anestrus. Anim. Reprod. Sci. 69: 199-209.

Knights, M., T. Hoehn, P. E. Lewis and E. K. Inskeep. 2001a. Effectiveness of intravaginal progesterone inserts and FSH for inducing synchronized estrus and increasing lambing rate in anestrous ewes. J. Anim. Sci. 79:1120-1131.

Knights, T. D. Maze, P. J. Bridges, P. E. Lewis, E. K. Inskeep. 2001b. Short-term treatment with a controlled internal drug-releasing (CIDR) device and FSH to induce fertile estrus and increase prolificacy in anestrous ewes. Theriogenology 55:1181-1191.

Land, R.B. 1978. Reproduction in young sheep: some genetic and environmental sources of variation. J. Reprod. Fert. 52:427-436.

Laster, D.B., Glimp, H.A. and Dickerson, G.E. 1972. Factors affecting reproduction in ewe lambs. J. Anim. Sci. 35:79-83.

Laster, D.B. and Glimp, H.A. 1974. Influence of breed on response to exogenous hormones in estrous and anestrous ewes. J. Anim. Sci. 39:1129-1135.

Lax, J., French, L.R., Chapman, A.B., Pope, A.L. and Casida, L.E. 1979. Length of breeding season for eight breed groups of sheep in Wisconsin. J. Anim. Sci. 49:939-942.

Legan, S.J., Karsch, F.J. 1983. Importance of retinal photoreceptors to the photoperiodic control of seasonal breeding in the ewe. Biol. Reprod. 29: 316-325.

Lewis, P.E., Bolt, D.J. and Inskeep, E.K. 1974. Pattern of luteinizing hormone release in progestin treated ewes. J. Anim. Sci. 38:1204-1209.

Lindsay, D. R. and Robinson, T. J. 1961. Studies of the efficiency of mating in the sheep. I. The effect of paddock size and number of rams. J. Agric. Sci. 57:137-140.

Lindsay, D. R. and Robinson, T. J. 1961. Studies of the efficiency of mating in the sheep. II. The effect of freedom of rams, paddock size, and age of ewes. J. Agric. Sci. 57:141-143.

Lopez-Sebastian, A., Gomez-Brunet, A. and Inskeep, E.K. 1984. Effects of a single injection on the response on anestrous ewes to the introduction of rams. J. Anim. Sci. 59:277-283. 
Lopez-Sebastian, A. Alonso De Miguel, W., and Gomez Brunet, A. 1985. Caracteristicas del comienzo de la pubertad en corderas Manchegas mediante la estimulacion por machos en estacion desfavorable. An. INIA / Ser. Ganadera 22:167-181.

Lopez-Sebastian, A. and Inskeep, E.K. 1991. Response of ewes of Mediterranean sheep breeds to subcutaneous implants of melatonin. Livest. Prod. Sci. 27:177-184.

Lopez-Sebastian, A., Gonzalez de Bulnes, A., Santiago Moreno, J., Gomez-Brunet, A., Townsend, E.C. and Inskeep, E.K. 1997. Patterns of follicular development during the estrous cycle in monovular Merino del Pais ewes. Anim. Prod. Sci. 48:279-291.

Mallampati, R.S., Pope, A.L. and Casida, L.E. 1971. Breeding pattern in Targhee ewes and ewe lambs throughout the year. J. Anim. Sci. 33:1278-1281.

Malpaux, B., Robinson, J.E., Wayne, N.L., Karsch, F.J. 1989. Regulation of the onset of the breeding season of the ewe: importance of long days and of an endogenous reproductive rhythm. J. Endocrinol. 122, 269-278.

Malpaux, B., Viguié, C., Skinner, D.C., Thiery, J.C., Chemineau, P. 1997. Control of the circannual rhythm of reproduction by melatonin in the ewe. Brain Res. Bull. 44, 431-438.

Malpaux, B., Daveau, A., Maurice-Mandon, F., Durate, G. and Chemineau, P. 1998. Evidence that melatonin acts in the premammillary hypothalamic area to control reproduction in the ewe: Presence of binding sites and stimulation of luteinizing hormone secretion by in Situ Microimplant Delivery. Endocrinology 139:1508-1516.

Martin, G.B., Cognie, Y., Schirar, A., Nunes-Rineiro, A., Fabre-Nys, C. and Thiery, J.C. 1985. Diurnal variation in the response of anoestrous ewes to the ram effect. J. Reprod. Fert. 75:275284.

Matthews, C.D., Seamark, R.F. and Guerin, M.V. 1992. Plasma melatonin profiles of Romney Marsh sheep in natural photoperiod and in acutely extended darkness. J. Reprod. Fert. 95:869875.

Meyer, H.H. and French, R.L. 1979. Hogget liveweight-oestrus relationship among sheep breeds. Proceedings of the New Zealand Society of Animal Production. 39:56-62.

Minton, J.E. 1990. Role of photorefractoriness in onset of anoestrus in Rambouillet x Dorset ewes. J. Reprod. Fert. 89:261-268.

Nett, T.M. and Niswender, G.D. 1982. Influence of exogenous melatonin on seasonality of reproduction in sheep. Theriogenology 17:645-653.

Notter, D.R. and Chemineau, P. 2001. Nocturnal melatonin and prolactin plasma concentrations in sheep selected for fertility in autumn lambing. J. Anim. Sci. 79:2895-2901.

Notter, D.R. 2012. Genetic improvement of reproductive efficiency of sheep and goats. Anim. Reprod. Sci. 130:147-151. 
Nowak, R. and Rodway, R.G. 1985. Effect of intravaginal implants of melatonin on the onset of ovarian activity in adult and prepubertal ewes. J. Reprod. Fert. 74:287-293.

O’Callaghan, D., Karsh, F.J., Boland, M.P. and Roche J.F. 1991. What photoperiodic signal is provided by a continuous-release melatonin implant? Biol. Reprod. 45:927-933.

Pellicer-Rubio, M.T., Leboeuf, B., Bernelas, D., Forgerit, Y., Pougnard, J.L., Bonne, J.L., Senty, E., Chemineau, P. 2007. Highly synchronous and fertile reproductive activity induced by the male effect during deep anoestrus in lactating goats subjected to treatment with artificially long days followed by a natural photoperiod. Anim. Reprod. Sci. 98, 241-258.

Perkins, A. and Fitzgerald, J.A. 1994. The behavioral component of the ram effect: The influence of ram sexual behavior on the induction of estrus in anovulatory ewes. J. Anim. Sci. 72:51-55.

Pirl, K.G. and Adams, T.E. 1987. Induction of precocious puberty in ewe lambs by pulsatile administration of GnRH. J. Reprod. Fert. 80:355-359.

Quirke, J.F., Stabenfeldt, G.H and Bradford, G.E. 1985. Onset of puberty and duration of the breeding season in Suffolk, Rambouillet, Finnish Landrace, Dorset and Finn-Dorset ewe lambs. J. Anim. Sci. 60:1463-1471.

Reeves, J.J., Arimura, A. and Schally, A.V. 1970. Studies on dose dependent response relationship of luteinizing hormone-releasing hormone (Lh-Rh) in sheep. J. Anim. Sci. 31:933936.

Reeves, J.J., Arimura, A. and Schally, A.V. 1971. Changes in Pituitary responsiveness to lutenizing hormone-releasing hormone (LH-RH) in anestrous ewes pretreated with estradiol benzoate. Biol. Reprod. 4:88-92

Reeves, J.J., Tarnavsky, G.K. and Chakraborty, P.K. 1974. Serum LH in ewes treated with synthetic luteinizing hormone-releasing hormone/follicle stimulating hormone-releasing hormone (LH-RH/FSH-RH) at three periods of anestrus. J. Anim. Sci. 38:369-373.

Rekik, M., Bryant, M.J. and Cunningham, F.J. 1991. Effects of treatment with melatonin on the response of seasonally anovular ewes to the introduction of rams. Anim. Prod. 53:203-207.

Robinson, J.E. and Karsch, F.J. 1984. Refractoriness to inductive day lengths terminates the breeding season of the Suffolk ewe. Biol. Reprod. 31:656-663.

Robinson, J.E., Wayne, N.L. and Karsch, F.J. 1985. Refractoriness to inhibitory day length initiates the breeding season of the Suffolk ewe. Biol. Reprod. 32:1024-1030.

Rollag, M.D., O’Callaghan, P.L. and Niswender, G.D. 1978. Serum melatonin concentrations during different stages of the annual reproductive cycle in ewes. Biol. Reprod. 18:279-285. 
Sharma, T.P., Herkimer, C., Ye, W., Birch, R., Robinson, J.E., Foster, D.L. and Padmanabhan, V. 2002. Fetal programming: Prenatal androgen disrupts positive feedback action of estradiol but does not affect timing of puberty in female sheep. Biol. Reprod. 66:924-933.

Sheffel, C.E., B.R. Pratt, W.L. Ferrell and E.K. Inskeep. 1982. Induced corpora lutea in the postpartum beef cow. II. Effects of treatment with progestogen and gonadotropins. J. Anim. Sci. 54:830-836.

Slyter, A. L., Hanson, D., Anderson, G., Read, B., Iman, N. 1997. Effect of extended light on growth and fall reproductive performance of crossbred ewe lambs. South Dakota State University Sheep Day (4 pages). http://ars.sdstate.edu/Sheep/SheepExt/sheepday97/97-2.htm Accessed 10/7/2011.

Smith, M.F., Swartz, H.A., Kiesling, D.O. and Warren Jr, J.E. 1986. Effect of ram exposure and prostaglandin F2 $\alpha$ on the reproductive performance on anestrous ewes. Theriogenology. 26:829835 .

Southam, E.R., Hulet, C.V. and Botkin, M.P. 1971. Factor influencing reproduction in ewe lambs. J. Anim. Sci. 33:1282- 1287.

Squires, E.L., Scaramuzzi, R.J., Caldwell, B.V. and Inskeep, E.K. 1972. LH Release and ovulation in the prepubertal lamb. J. Anim. Sci. 34:614-619.

Stellflug, J.N, Fitzgerald, J.A. and Parker, C.F. 1989. Effect of melatonin and extended light on reproductive performance of fall-born Polypay ewe lambs and ewes during spring breeding. Theriogenology 32:995-1005.

Stellflug, J.N. 1992. A review of use of melatonin in sheep. In: Proceedings of the Out-of-Season Breeding Symposium, Iowa State Cooperative Extension, Ames, IA 82-97

Stellflug, J.N., Rodriguez, F., LaVoie, V.A., Glimp, H.A. 1994. Influence of simulated photoperiod alteration and induced estrus on reproductive performance of spring-born Columbia and Targhee ewe lambs. J. Anim. Sci. 72, 29-33.

Sunderland, S.J., O'Callaghan, D., Boland, M.P. and Roche, J.F. 1995. Effect of photoperiod before and after birth on puberty in ewe lambs. Biol. Reprod. 53:1178-1182.

Suttie, J.M., Foster, D.L., Veenvliet, B.A., Manley, T.R. and Corson, I.D. 1991. Influence of food intake but independence of body weight on puberty in female sheep. J. Reprod. Fert. 92:3339 .

Sweeney, T., Donovan, A., Karsch, F.J., Roche, J.F. and O'Callaghan, D. 1997. Influence of previous photoperiodic exposure on the reproductive response to a specific photoperiod signal in ewes. Biol. Reprod. 56:916-920.

Underwood, J.L., Shier, F.L. and Davenport, N. 1944. Studies in sheep husbandry in Western Australia: V. the breeding season of Merino, crossbred and British breed ewes in the agricultural districts. J. Dept. of Agric. West Aust. 21:135-143. 
Valsai, I., Chadio, S., Fthenakis, G. C., Amiridis, G.S. 2012. Management of pre-pubertal small ruminants: Physiological basis and clinical approach. Anim. Reprod. Sci. 130: 126-134.

Viguié, C., Caraty, A., Locatelli, A., Malpaux, B. 1995. Regulation of LHRH secretion by melatonin in the ewe. I. Simultaneous delayed increase in LHRH and LH pulsatile secretion. Biol. Reprod. 52, 1114-1120.

Vincent, J.N., McQuown, E.C. and Notter, D.R. 2000. Duration of the seasonal anestrus in sheep selected for fertility in a fall-lambing system. J. Anim. Sci. 78:1149-1154.

Viñoles, C., Meikle, A., Forsberg, M. and Rubianes, E. 1999. The effect of subluteal levels of exogenous progesterone on follicular dynamics and endocrine patterns during the early luteal phase of the ewe. Theriogenology 51:1351-1361.

Viñoles, C., Forsberg, M., Banchero, G. and Rubianes, E. 2001. Effect of long-term and shortterm progestagen treatment on follicular development and pregnancy rate in cyclic ewes.

Theriogenology. 55 :993-1004.

Walkden-Brown, S.W., Martin, G.B. and Restall, B.J. 1999. Role of male-female interaction in regulating reproduction in sheep and goats. J. Reprod. Fert. Suppl. 52:243-257.

Waller, S.L., Hudgens, R.E., Diekman, M.A. and Moss, G.E. 1988. Effect of melatonin on induction of estrous cycles in anestrous ewes. J. Anim. Sci. 66:459-463.

Welch, R.A.S. 1984. Development of CIDR dispensers for use in nulliparous ewes. N. Z. Ministry of Agric. \& Fish. Agric. Res. Div. Annu. Rep., 1983/84. p 58. Wellington, New Zealand.

Wheaton, J.E., Windels, H.F. and Johnston, L.J. 1992. Accelerated lambing using exogenous progesterone and the ram effect. J. Anim. Sci. 70:2628-2635.

Wiggins, E.L., Miller III, W.M. and Barker, H.B. 1970. Age at puberty in fall-born ewe lambs. J. Anim. Sci. 30:974-977.

Wildeus, S. 2000. Current concepts in synchronization of estrus: Sheep and goats. J. Anim. Sci. $77: 1-14$.

Williams, S.M., Garrigus, U.S., Norton, H.W., and Nalbandov, A.V. 1956. Variations in the length of estrus cycles and the breeding season in ewes. J. Anim. Sci. 15:984-989.

Worthy, K. and Haresign, W. 1983. Evidence that the onset of seasonal anoestrous in the ewe may be independent of increasing prolactin concentrations and daylength. J. Reprod. Fert. 69:4148.

Yellon, S.M., Foster, D.L. 1985. Alternative photoperiods time puberty in the female lamb. Endocrinology 116: 2090-2097. 
Yellon, S.M., Bittman, E.L., Lehman, M.N., Olster, D.H., Robinson, J.E. and Karsh, F.J. 1985. Importance of duration of nocturnal melatonin secretion in determining the reproductive response to inductive photoperiod in the ewe. Biol. Reprod. 32:523-529.

Yellon, S.M. and Foster, D.L. 1986. Melatonin rhythms time photoperiod-induced puberty in the female lamb. Endocrinology. 119:44-49

Zarazaga, L.A., Gatica, M.C., Celi, I. and Guzman, J.L. 2012. Reproductive performance is improved during seasonal anoestrous when female and male Murciano-Granadina goats receive Melatonin implants and in Payoya goats when females are thus treated. Reprod. Dom. Anim. 47:436-442. 


\section{Vita}

Name: Matthew Lewis Deacon

Parents: Waitman Lewis and Sarah Jane Deacon

Birthplace: Lexington, Virginia

Date of Birth: November 4, 1987

Schools Attended:

Mountain View Elementary School: 1992-1999

Rockbridge Middle School: 1999-2002

Rockbridge County High School: 2002-2006

Dabney S. Lancaster Community College: 2006-2007

Potomac State College: 2007-2010

West Virginia University (Undergraduate): 2010-2011

West Virginia University (Graduate): 2011- Present

Degrees Received

A. A., Animal Science, Potomac State College

B. S., Animal and Nutritional Sciences, West Virginia University

Experience:

Research Assistant, West Virginia University, Morgantown, West Virginia 


\section{Approval of the Examining Committee}

Emmett K. Inskeep, Ph.D., Chair

Eugene E. Felton, Ph.D.

Marlon Knights, Ph.D. 